Payman (Charing Cross Hospital) and Dr. G. W. Scott-Blair (National Institute for Research in Dairying, University of Reading). The discussion on "Some Recent Research Problems encountered in the Study of Blood as a Rheological Fluid" was opened by Drs. D'A. Kok (Department of Medicine) and P. A. G. Munto (Anatomy School). A lively exchange of ideas followed with contributions mainly by the opening speakers and Drs. P. Johnson and A. T. Rowe (Department of Colloid Science), Dr. P. R. Lewis (Anatomy School) and Dr. N. A. de Bruyne (Techne, Ltd.). It was announced that the next meeting would take place at the Technological Research Station, Spillers, Ltd., on September 11, when the Cambridge Instrument Company, Ltd., Grant Instruments (Cambridge), Ltd., and Techne (Cambridge), Ltd., will exhibit and discuss rheological equipment. Further information can be obtained from Mr. H. G. Muller, Technological Research Station, Spillers, Ltd., Station Road, Cambridge.

\section{British Conference on Insecticides and Fungicides}

THE Association of British Manufacturers of Agricultural Chemicals is organizing a "British Insecticide and Fungicide Conference" at the Grand Hotel, Brighton, during November 6-9. The conference is divided into eleven sessions, which include: (a) soil pests and diseases, including "The Eelworm Problem", by Mr. F. Jones, "Insecticide Seed Dressings" by Mr. M. J. Way and "Fungicide Seed Dressings" by Dr. Mary Noble; (b) systemic insecticides, including "Systemic Insecticides and Virus Control in Potatoes" by Dr. L. Broadbent and "Control of Sugar Beet Virus Yellows" by Dr. Reitberg; (c) forecasting of pest and disease outbreaks (Mr. G. H. Brenchley); $(d)$ the control of apple mildew (Dr. R. T. Burchill); (e) pests of tree fruits (Dr. G. H. Dicker); $(f)$ control of Botrytis disease (Mr. J. M. Wey); $(g)$ control of fungi and nematodes (Dr. Madel); $(h)$ newly developed compounds; $(i)$ introduction of insecticides into agricultural practice at home and abroad (Mr. M. Cohen and Mr. G. Ordish). Further information can be obtained from the conference secretary, Mr. W. A. Williams, Association of British Manufacturers of Agricultural Chemicals, Cecil Chambers, 86 Strand, London, W.C.2.

\section{New Universities in Britain}

IN a written answer given in the House of Commons on May 18, the Chancellor of the Exchequer, Mr. Selwyn Lloyd, said that the University Grants Committee had advised him that, within the scope of the building programme already announced, four new universities, in addition to those which are already being established at Brighton, Norwich and York should be established as the best means of providing places for some of the increased number of students expected. He added that the Committee had advised him that three of the four should be at Canterbury, Colchester and Coventry. The location of the fourth is being considered and the Committee hoped to report on this in the next two or three months. It is the Committee's view that the question of the establishment of any new universities beyond these four should await the report of Lord Robbins's Committee on Higher Education. No new university for Scotland was proposed because it was expected that the expansion of the existing Scottish institutions under the building programme already authorized would provide the additional places needed. Mr. Lloyd said he had accepted this advice, and had authorized the University Grants Committee to enter into discussions accordingly. The detailed proposals would take into account existing provision and plans for other forms of higher education in the areas concerned.

\section{Announcements}

DR. T. D. DAY, formerly assistant director of cancer research, Department of Experimental Pathology and Cancer Research, University of Leeds, has been appointed to direct the Tobacco Manufacturers' Standing Committee Research Unit, Harrogate.

THE following were elected officers of the Salters' Company for the year 1961-62: Master, Sir Alexander Todd; Upper Warden, T. G. Hicks; Second Warden, Rear-Admiral W. K. Weston.

THE 407th meeting of the Biochemical Society will be held in the Department of Physiology and Biochemistry, University of St. Andrews, during June 22-23, starting at 2 p.m., when there will be a colloquium on "The Quantitative Estimation of Amino Acids". Original communications will be presented on the following day.

THe National Physical Laboratory, Teddington, is organizing a conference on "The Control of Noise" during June 26-28, in collaboration with the National Engineering Laboratory and the Building Research Station. The programme will include: general problems of the control of noise; hearing and the ear ; measuring noise ; sources of mechanical noise; propagation of sound in air; effects of noise on performance and productivity, etc. Further information can be obtained from Mr. D. W. Robinson, National Physical Laboratory, Teddington, Middlesex.

THE eleventh meeting of Nobel prize winners will be held in Lindau during June 26-30. Further information can be obtained from the Sekretariat der Tagungen für Nobelpreisträger, Lindau (Bodensee), Postfach 11.

Hatrield College of Technology is organizing a summer school on the "Mathematics of Automatic Control" during June 26-30. The object of this school is to enable mathematicians and engineers working on problems of automatic control to study some of the relevant mathematical techniques developed in recent years in Britain, the United States and the U.S.S.R. Further information can be obtained from the Academic Registrar, Hatfield College of Technology, Hatfield, Herts.

THe Association for the Study of Animal Behaviour is holding a three-day symposium on "Orientation and Migration" during July 11-13 in the Department of Zoology, University of Cambridge. Further information can be obtained from Dr. J. B. Free, Rothamsted Experimental Station, Harpenden, Herts.

Erratum. In the article entitled "Separation of Two Light Reactions in Noncyclic Photo-phosphorylation of Green Plants", by Dr. M. Losada, Dr. F. R. Whatley and Prof. Daniel I. Arnon, in Nature of May 13, p. 606, in Tables 2 and 3 , entries 2 and 4, the plus sign should in each case precede the word 'Dye'. 